\title{
DELAYED DEBRIDEMENT FOR NECROTIZING SOFT TISSUE INFECTIONS: EXPERIENCE WITH IMMUNOCOMPROMISED PEDIATRIC CANCER PATIENTS.
}

\author{
By
}

\author{
Kareem Sallam $^{(1)}$, Maged Mostafa ${ }^{(2)}$, Lobna Shalaby ${ }^{(3)}$, Yousef Medany ${ }^{(3)}$, \\ Aly Moustafa ${ }^{(4)}$, Ameera Sayed ${ }^{(4)}$, Mohamed Raslan ${ }^{(5)}$ and Hussein \\ Khairy $^{(5)}$ \\ ${ }^{(1)}$ Department of Surgery, Faculty of Medicine, Helwan University \\ ${ }^{(2)}$ Department of Surgery, Liver Diseases Institute, Cairo \\ ${ }^{(3)}$ Department of Pediatric Oncology, National Cancer Institute, Cairo University \\ ${ }^{(4)}$ Department of Intensive Care Medicine; Children's Cancer Hospital \\ ${ }^{(5)}$ Department of Surgery, Faculty of Medicine, Cairo University
}

\begin{abstract}
Background: Standard management of necrotizing soft tissue infections (NSTI) includes combination of antimicrobial chemotherapy, supportive care and surgical debridement. Debridement is often done very early in the course of illness to remove dead tissue. Fatality rates from this condition are very high.

Objective: To evaluate the strategy of delayed rather than early debridement in the management of NSTI in immunocompromised hematologic malignancy patients.

Patients and Methods: Twenty patients included in the study. All were immunocompromised pediatric patients on cancer treatment who present with necrotizing soft tissue infection. Debridement was deferred on initial presentation. After stabilization of the general condition of the patients and improvement of the local conditions by developing line of demarcation between the necrotic area and the inflamed area, the patients underwent delayed debridement in the O.R with excision of the overtly dead tissue only.
\end{abstract}

Results: There were 13 males and 7 females with age ranging from 9 months to 16 years. After initial treatment with antibiotics, in 7 out of 20 patients the antibiotics alone succeeded to halt the progress of infection. In the remaining 13, the process proceeded to SIRS and MODS. They required ICU admission for a range of monitoring and organ support. Only one patient died. The remaining 12 required significant debridement and later grafting of the bare area after development of the healthy granulation tissue. Good functional outcome of the affected part was achieved with the aid of variable physiotherapy courses.

Conclusion: NSTI in immunocompromised patients with cancer is a pathology known of high fatality rate. Delayed rather than early debridement was associated with low mortality rates and limb preservation with good functional outcome.

\section{INTRODUCTION}

Necrotizing infection is a disease known for lethality. The number of organisms involved is the main discriminating factor separating two entities named as type 1 and type 2 infections, of which type 1 is monomicrobial while type 2 is multimicrobial (Steven and Bryant, 2017). 
In some studies, type II infections have accounted for 55 to $87 \%$ of all cases of necrotizing fasciitis (Jabbour et al., 2015 and Novrdqvist et al., 2015) whereas type I infections have been more prevalent in other studies (van Stigt et al., 2016) and in some studies, the incidence of the two types of infection has been similar (Devaney et al., 2015 and Kulasegarnas et al., 2016).

The recognition of the multimicrobial nature in the majority of these infections took place more than two decades ago. In addition, it has been realized that the process does not restrict itself to a certain tissue type and hence the development of the collective term NSTI instead of necrotizing fasciitis, clostridia myonecrosis, etc. (Howard et al., 1999).

The paucity of cutaneous findings early in the course of NSTI makes diagnosis difficult. Necrotizing infections in children is frequently misdiagnosed as simple soft tissue infections such as cellulitis, these results in delay in treatment. Presence of vesiculation, ecchymosis, crepitus, anesthesia, and necrosis are indicative of advanced disease. It is therefore important to diagnose NSTI before skin necrosis develops.

Standard management of the NSTI includes combination of antimicrobial chemotherapy, supportive care in an intensive care setting and surgical debridement (Marron et al., 2010).

Debridement is often performed early in the course of the disease in an attempt to decrease the septic load and hence improve the general condition of the patient (Steven and Brayant, 2017).
The fatality rate despite the efforts and the strategy mentioned reaches as high as 80\% (Magala et al., 2014 and Puvanendran et al., 2009).

Treatment outcome of NSTI in immunocom promised patients using these strategies reveals even worse outcome.

NSTI in immunocom promised patients might need revision of the strategy of early debridement. The infection is always extensive and spreads along a large area of the patient's body owing to the exceptionally weak immune system of the patient.

Debridement of the dead tissue early in the course of the disease probably removes only small percentage of the septic load with a drawback of opening and leaving large raw area in an already immunocom promised patient liable to invasion by microorganisms from the surrounding environment.

This work presented the results of delayed rather than early debridement for patients with NSTI in which debridement was performed only after a period of intensive antimicrobial and intensive care.

\section{PATIENTS AND METHODS}

Twenty pediatric cancer patients under cancer treatment in National Cancer Institute (NCI) and Children's Cancer Hospital $(\mathrm{CCH})$ who developed NSTI in various anatomical sites were managed by delayed debridement strategy. The patient was included in the study when there was visible area of skin devitalization. Patients with edema and other signs of inflammation without devitalized skin visible to the examiner were not included in the study regardless the systemic 
condition and magnitude of affection. Chemotherapeutics were stopped, and patients were admitted to ICU for monitoring and organ support as needed.

Rather than going for aggressive immediate debridement, a non-operative strategy was adopted initially consisting of intensive antimicrobial therapy and intensive pharmacological and mechanical organ support (the rationale for which was pointed-to in the introduction and given in details in the discussion section).

No specific time interval was awaitedfor to indicate going for debridement. Instead, the end point of the non-operative management was defined by:

\section{Local improvement as indicated by:}

a. Improvement of signs of inflammation in terms of area affected and magnitude of affection.

b. Occurrence of line of demarcation and preferably a line of separation between dead and living -though not perfectly healthy- tissues.

2. Systemic improvement as indicated by:

Withdrawal of organ support required for management of sepsis induced systemic inflammatory response syndrome (SIRS) and multi organ system dysfunction syndrome (MODS).

Patients who required organ support for causes other than multi organ dysfunction syndrome induced by sepsis were still candidates for debridement. Absolute normalization of vital signs and laboratory values was not considered as a required end point.

Antibiotic therapy: The policy implemented is liberal; empirical multidrug antimicrobial therapy including systemic antifungal treatment. Cultures, though sent for, were not awaited.

\section{Adjunctive interventions:}

1. Pain control.

2. Limb splinting to avoid joint contractures.

3. Nutritional support.

\section{Surgical Management:}

When the previously mentioned end points were met, debridement is performed removing only the dead tissue. The wound is left open for later grafting.

Figures (1) and (2) showed examples of the aforementioned management strategy at its different stages. 

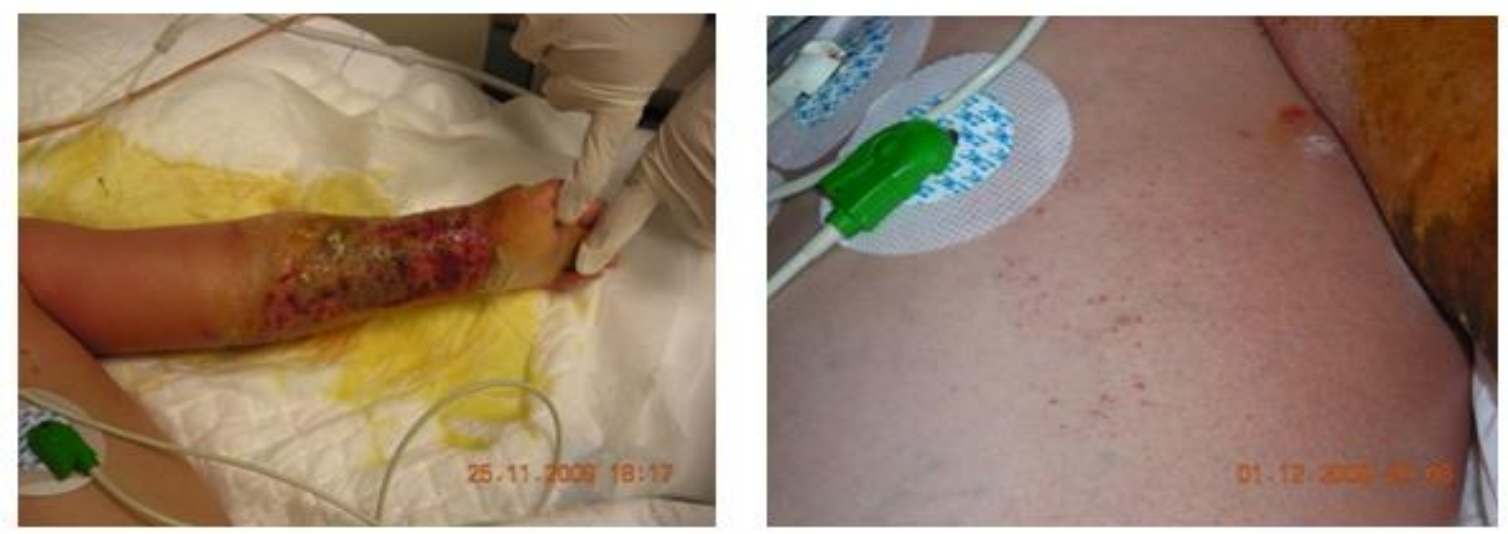

Figure (1a): A patient with NSTI in the left upper limb.

Lt: NSTI in the left upper limb at the time of diagnosis. Rt: Note the extension of the inflammation to the left side of chest.

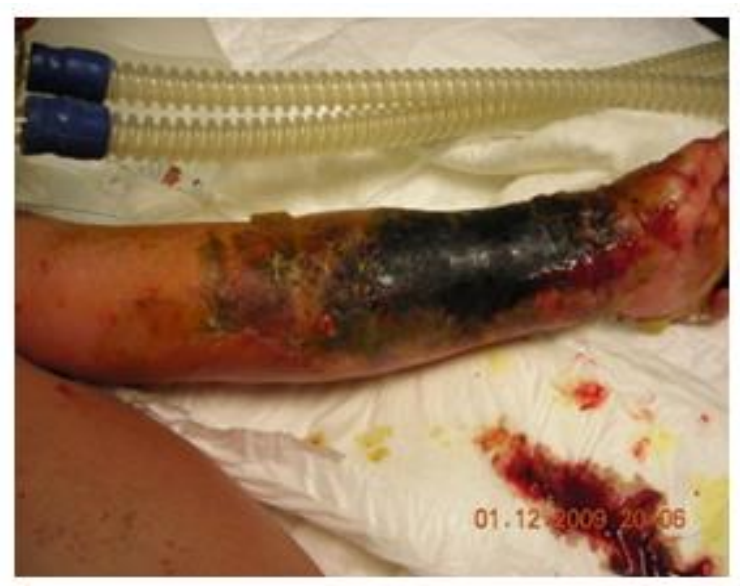

Figure (1b): The patient after development of line of demarcation and separation between inflamed and dead tissue in ICU settings. The local and systemic condition improved now ready for debridement.

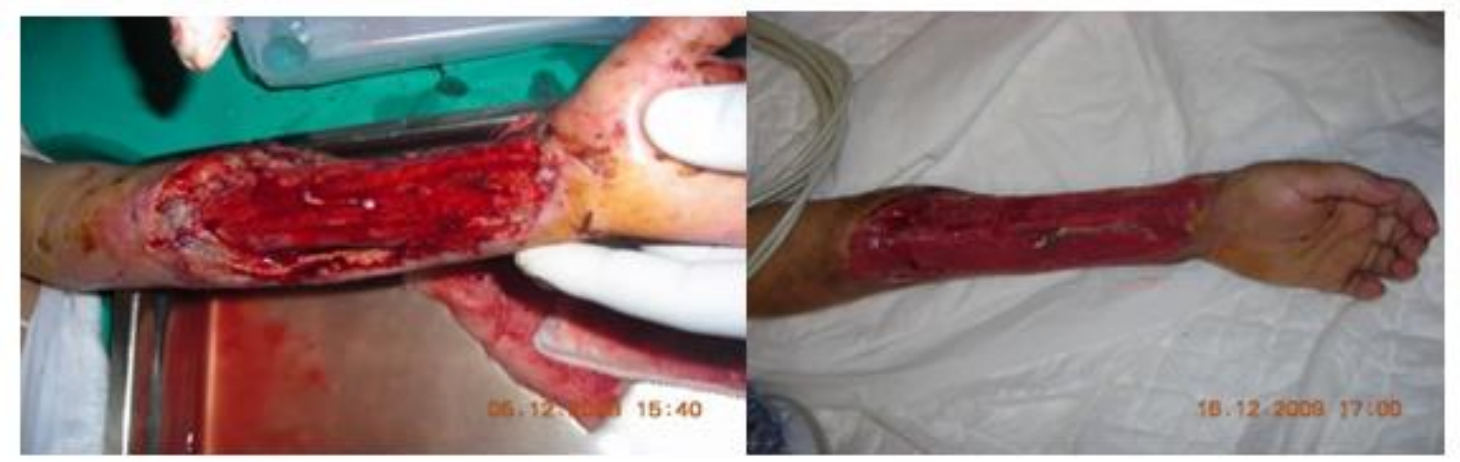

Figure (1c): Lt: the patient just after debridement has been done. Rt: the affected area after repeated dressings with development of healthy granulation tissue now ready for grafting. 

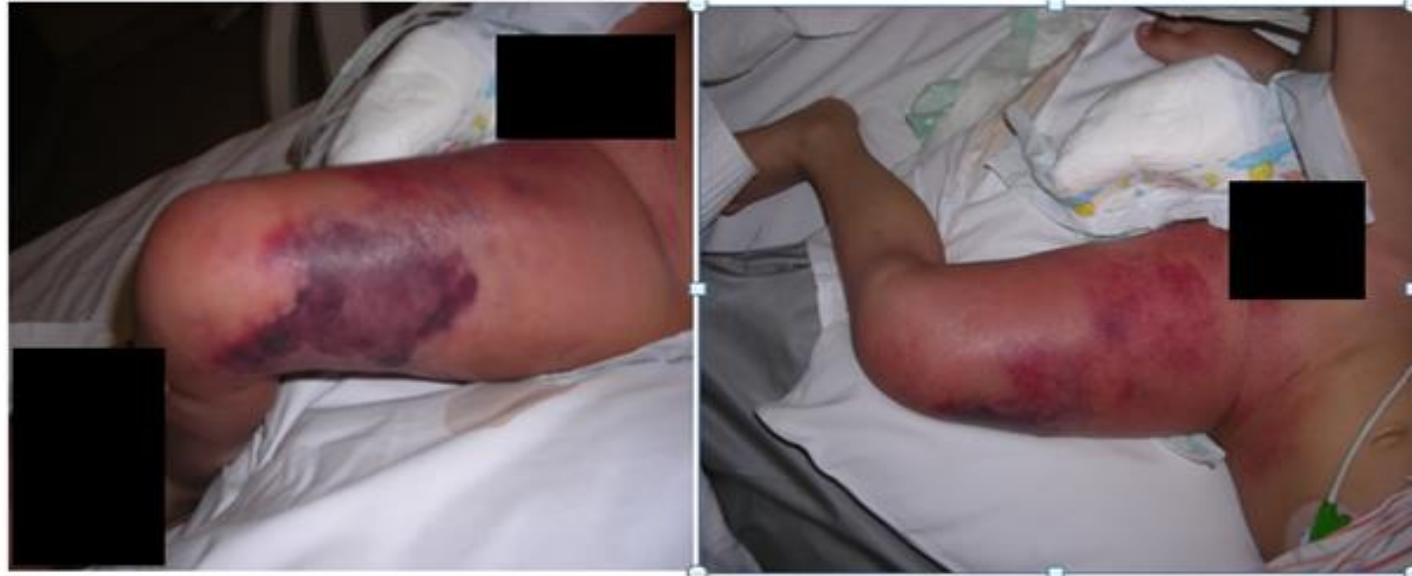

Figure (2a): A patient with NSTI in the left thigh at the time of diagnosis. Note that there is no line of demarcation between inflamed and dead tissues and there is extensive inflammation of the whole limb.

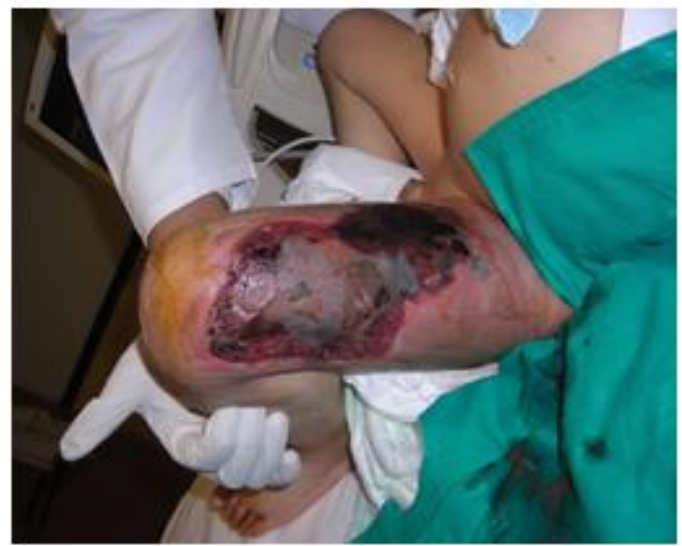

Figure (2b): The patient after development of line of demarcation and separation between inflamed and dead tissues. Note the improvement of the surrounding inflammation and oedema as compared to figure $2 \mathrm{a}$.

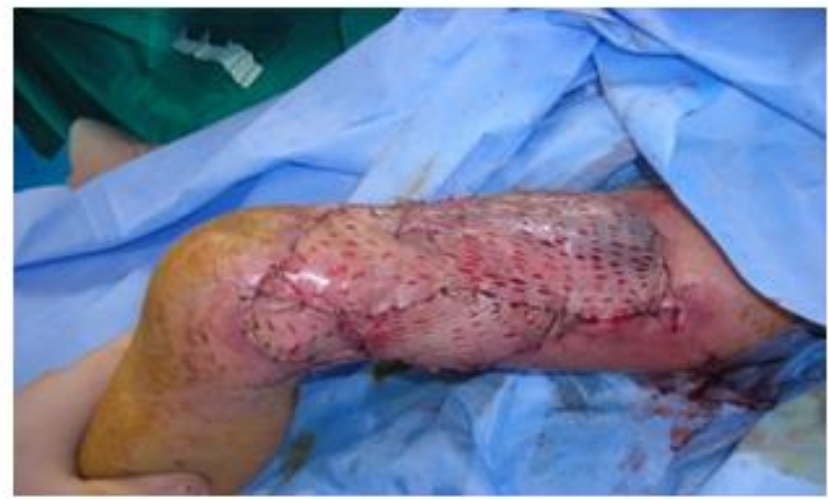

Figure (2c): The patient after debridement and coverage by skin graft. 


\section{RESULTS}

Twenty patients were included in the study characteristics of patients are given in table 1. There were 13 males and 7 females. Age range was $9 \mathrm{~m}$ to $16 \mathrm{y}$. Regarding the type of malignancy; 17 patients had hematologic malignancies and 3 had solid tumors. At time of NSTI; 12 patients were on more than 2 agents, 7 were on 2 or less and 1 patient was not chemotherapy. Nineteen patients had extremity infections and one had head and neck infection. In 16 out of 20 patients, cannula site infection was suspected to be the triggering factor of NSTI.

Antibiotics succeeded to halt the process of infection in 7 patients. So, they had no need to be admitted in ICU settings as they had no signs of sepsis. So, debridement and grafting were done. In the remaining 13 patients the process of inflammation proceeded to SIRS and MODS. They had to be admitted in ICU for a range of pharmacological and mechanical organ support measures (Table 1).

Main outcome measure: In a year time post the event of NSTI, only two out of 20 patients died. One died in the early course of NSTI, while the other died after 1 year of debridement after myleoablative therapy which was not related to the NSTI event.

Only one patient required second debridement to excise more dead tissue after the first operation. Two patients developed joint contractures that required long duration of physiotherapy later. 
Table (1): Characteristics of patients included in the study

\begin{tabular}{|c|c|c|c|c|c|c|}
\hline No & Age & Gender & $\begin{array}{l}\text { Primary } \\
\text { diagnosis }\end{array}$ & $\begin{array}{l}\text { Chemotherapy } \\
\text { received }\end{array}$ & $\begin{array}{l}\text { Organ } \\
\text { support }\end{array}$ & Antibiotics \\
\hline 1 & $9 \mathrm{~m}$ & $\mathrm{~F}$ & $\begin{array}{l}\text { brain tumor } \\
\text { (thalamic) }\end{array}$ & no chemotherapy & Not needed & Meronam, Vancomycin \\
\hline 2 & $16 \mathrm{y}$ & $\mathrm{F}$ & AML & CYT, DAU & Not needed & Tazocine, Vancomycin \\
\hline 3 & $2 y$ & M & NB & $\begin{array}{l}\text { CIS,CYCLO, VIN, } \\
\text { DOX }\end{array}$ & Not needed & $\begin{array}{c}\text { Tazocine , Amikacin, } \\
\text { Dalacin }\end{array}$ \\
\hline 4 & $2 y$ & $\mathrm{M}$ & NHL & 6MERC, DOX & Not needed & Co-trimoxazole \\
\hline 5 & $6 y$ & $\mathrm{~F}$ & HL & ADR,VINB, BLEO & needed & $\begin{array}{l}\text { Meronam,Vancomycin, } \\
\text { Zithromax,Tazocine }\end{array}$ \\
\hline 6 & $11 \mathrm{y}$ & M & $\begin{array}{l}\text { NHL (burkitt's } \\
\text { lymphom) }\end{array}$ & $\begin{array}{l}\text { CYCLO, ADR, } \\
\text { METHO }\end{array}$ & needed & $\begin{array}{l}\text { Meronam, Clindamycine, } \\
\text { Fungisone, Tazocine }\end{array}$ \\
\hline 7 & $9 y$ & $\mathrm{~F}$ & ALL (T cell) & CYT, METHO & needed & $\begin{array}{l}\text { Tazocine, Amikacine, } \\
\text { Meronam, Vancomycine }\end{array}$ \\
\hline 8 & $3 y$ & M & ALL & $\begin{array}{l}\text { 6MERC, VIN, } \\
\text { METHO }\end{array}$ & needed & $\begin{array}{c}\text { Cipro,Meronam, } \\
\text { Vancomycine,Flagyl }\end{array}$ \\
\hline 9 & $15 \mathrm{y}$ & M & ALL & 6MERC, DOX, VIN & needed & Ciprofloxacine \\
\hline 10 & $7 y$ & M & ALL & $\begin{array}{c}\text { 6MERC, VIN, } \\
\text { METHO }\end{array}$ & needed & $\begin{array}{l}\text { Meronam, Vancomycin, } \\
\text { Zithromax,tazocine }\end{array}$ \\
\hline 11 & $22 \mathrm{~m}$ & M & ALL & 6MERC, DOX, VIN & needed & $\begin{array}{c}\text { Cipro,Meronam, } \\
\text { Vancomycine, Tazocine }\end{array}$ \\
\hline 12 & $14 \mathrm{y}$ & $\mathrm{M}$ & NHL (T-cell) & 6MERC, DOX & needed & Meronam,Vancomycin \\
\hline 13 & $15 y$ & $\mathrm{~F}$ & AML & CYT, DOX & needed & $\begin{array}{l}\text { Tigecyclin, Meronam, } \\
\text { Flagyl Vancomycine, }\end{array}$ \\
\hline 14 & $19 \mathrm{~m}$ & M & NB & DOX, VIN, CYCLO & Not needed & $\begin{array}{l}\text { Curam, Dalacine c } \\
\text { Ciprofloxacine, }\end{array}$ \\
\hline 15 & $5 \mathrm{y}$ & M & ALL (T cell) & CYT, METHO & Not needed & $\begin{array}{l}\text { Tazobactam, Piperacillin, } \\
\text { Amikin Vancomycin, }\end{array}$ \\
\hline 16 & $2 y$ & M & NB & $\begin{array}{c}\text { DOX, VIN, } \\
\text { CYCLO,CIS } \\
\end{array}$ & needed & $\begin{array}{l}\text { Augmentin ,Tazocin, } \\
\text { Dalacine Amikacin, }\end{array}$ \\
\hline 17 & $2 y$ & M & ALL & 6MERC,VIN & needed & $\begin{array}{l}\text { Meronam, Vancomycin, } \\
\text { Gentamycin }\end{array}$ \\
\hline 18 & $13 y$ & M & ALL & $\begin{array}{c}\text { 6MERC,VIN, } \\
\text { METHO }\end{array}$ & needed & $\begin{array}{c}\text { Vancomycine, } \\
\text { Tazobactam, Amikacine }\end{array}$ \\
\hline 19 & $2 y$ & $\mathrm{~F}$ & ALL & $\begin{array}{l}\text { 6MERC,VIN, } \\
\text { METHO }\end{array}$ & needed & $\begin{array}{l}\text { Meronam, Vancomycin, } \\
\text { Tazocine Zithromax, }\end{array}$ \\
\hline 20 & $6 y$ & $\mathrm{~F}$ & HLH & CYT,DAU & Not needed & $\begin{array}{c}\text { Meronam Dalacine, } \\
\text { Vancomycine, } \\
\text { Ciprofloxacine }\end{array}$ \\
\hline
\end{tabular}

ADR: Adriamycin, AML: Acute Myeloid Leukemia, ALL: Acute Lymphoblastic Leukemia, BLEO: Bleomycin, CIS: Cisplatin CYCLO: Cyclophosphamide, CYT: Cytarabine, DAU: Daunorubicine, DOX: Doxorubicin, HL: Hodjkin's Lymphoma, HLH: Haemophagocytic Lymphohistiocytosis, METHO: Methotrexate, 6MERC:6 Mercaptopurine, NB: Neuroblastoma, NHL: Non Hodjkin's Lymphoma, VIN: Vincristine, VINB: Vinblastin.

\section{DISCUSSION}

It is well established in surgery and medicine that the presence of dead tissue inside the living body of a human being is a compromise to its physiological functions. Getting rid of which was in turn a logical and prudent recommendation.

Literature particularly recording the outcome of treatment of NSTI in haematologic cancer patients under chemotherapy is scarce. These patients are immunosuppressed by the effect of the disease as well as the treatment. They are a special situation.

There was not much to compare to. However, it is logical to assume a higher fatality rate for this subset of patients than 
KAREEM SALLAM et al.,

what is reported in literature for otherwise patients.

Fatality rates in NSTI in general reach as high as $80 \%$ series (Magala et al., 2014 and Puvanendran et al., 2009).

Though necrosis is the hall mark of necrotizing soft tissue infections, yet the pathology is not only about the necrotic tissue. There is often an extensive area of inflammation that surrounds and sometimes intervenes with the necrotic tissue. Systemic sepsis, when present, is the product of the 2 pathological processes; necrosis and extensive inflammation. More often than not that the necrotic tissue is far less in volume than the inflamed tissue.

The authors have been involved in the management of NSTI'S in immunocompromised haemtologic malignancy patients. The authors have realized how fast these infections advance locally as well as systemically. In an attempt to salvage the situation in a septic patient progressing towards the need for organ support, the authors used to rush them to operating rooms for debridement of dead tissue. The margin between the dead and the inflamed was never clear. It was so vague what has to come out and what can stay.

Six consecutive patients have died preoperatively adopting this policy of debridement despite all efforts to perfect it in terms of surgical technique and organ support. In each of these occasions perhaps no more than a fraction of the source of sepsis and inflammatory mediators has been removed. The extensively inflamed tissue was always left behind, for taking it all out would have meant an amputation, a call that is not in the list of options in the first place. The patients were left by open wounds in a context of negligible native immunity and under cover of antibiotics that was not effective in the first place.

Organisms that has managed to get through from a prick of a needle- which is the proposed usual scenario -now is having an extensive raw area serving as a portal of entry. It seemed like a winning formula, not for the treatment plan but for the pathology. A win that has been achieved systematically.

The scenario was a clear call to stop the rush for debridement. Instead; intensify antibiotics and antifungals, intensify the intensive care management and organ support and stay away until the end points given in the methods section are met.

The results of adopting such a policy have been shown in the results section. Only two in 20 patients have died and the rest had no limb or life loss.

Decision making as regards coverage of raw areas is as well a subject for customization rather than of routine and strictness.

A patient from this group was a kid who had his debridement recently. According to the usual standards we should have waited for the wound to get disinfected to render it "graftable". Burn surgeons practice wound cultures and even wound bacterial counts to indicate a graftable bed (Lenarz, 2010). However, the situation was that there was a certain window for control of his malignancy, he has to receive the treatment in 15 day's time or a grip will be lost and probably can never be claimed back. 
The wound was grafted only few days after debridement with a theoretical slim prospect of success of grafting. The graft healed completely and he was sent in time to receive the cytotoxic agents that can never be administered to a patient with an open wound.

The scenarios of this aforementioned kid are just an example that some unusual dismal outcomes do occur despite what seems as perfect conditions and treatment. In some other occasions some unusual desired outcomes do happen against what is recognized as prohibitive odds. When options are scarce and interests are conflicting, it is there chance to be proven as a possibility.

On the contrary, if no hurry exists as regards the resumption of chemotherapeutics the authors would recommend deferring the grafting even when the bed looks graftable. Not out of concern of poor take of the graft but out of concern about poor healing in the donor site. One of the patients took months to heal. It is preferable to have the general condition of the patient somehow permissible of healing before attempt of grafting, again if no hurry exists.

Vacuum assisted wound closure devices have shown excellent results in closure of raw areas (Baharestani, 2008, Lee et al., 2014 and Crew et al., 2013). They have been used in this series and were associated with remarkable results.

The authors would like to emphasize the role of limb splinting in order to prevent limb contractures and the need for lengthy physiotherapy post resolution of infection. Patients often acquire a flexion posture for the weeks of treatment as result of the pain, enough to induce the contractures.

The slab does not have to stay all day, instead, under sedation, the slab can be removed and the limb moved daily and then put again.

Should this strategy be examined in patients without serious immuncompromise?

The answer of this question is beyond the authors' experience. However, the authors will take the opportunity to raise the issue and leave the postulate to be examined by the properly experienced and a judgment is then to be made whether to adopt this or not. Not necessarily indiscriminately but at least selectively as appropriate.

At some points in the history of the treatment of peptic ulcer the mainstay of treatment shifted to become medical rather than surgical. Some point in the history and progression of the treatment of many malignancies- especially pediatric solid tumors- the timing of surgery has changed from becoming at the front of treatment to become at a second stage after preparation by a course of neoadjuvant chemotherapy. Maybe we are having a situation analogous to those here in the management of NSTI in the immunocompromised cancer patient.

At the time this work recommends delaying the debridement, it would recommend early implementation of organ support measures including the invasive modalities. The natural history of the pathology is one of several days and may be weeks. Keeping a high threshold for implementing invasive measures of organ support has the drawback of exhausting 
the patient's reserves and in the end; they will have to be used any way but now on a physiologically depleted patient. It seemed to the authors that in this pathology in this subset of patients once the patient started to show signs of organ function deficiency, he will never be able to make it on his own and the organ support will prove necessary. So better implement it preemptively.

Guide lines for intensive care management for such patients has been published, it is appreciated though that there still remains room for the caring physicians' assessment and judgement to each specific situation (Rhodes et al., 2016).

Adjunctive measures attempted for the treatment of this condition include hyperbaric oxygen, intravenous immunoglobulin (IVIG) and a new inhibitor of bacterial super antigens (Stevens and Bryant 2017). More than one study addressing hyperbaric oxygen did not show a clear benefit (Wang et al., 2003, Wiley et al., 2012 and Jallali et al., 2005). However, some more recent studies did find it useful (Devaney et al., 2015 and Shaw et al., 2014). Similarly, a consensus regarding the usefulness of IVIG has not been reached (Shah et al., 2009 and Kadr et al., 2017). Bacterial super antigen inhibitor showed no significant benefit (Bulgar et al., 2014).

\section{CONCLUSION}

In this cohort of patients with NSTI; delayed debridement strategy has been associated with relatively low mortality rates, organ and tissue preservation as well functional preservation.
Whether the approach can be applied in NSTI in adults with no documented immunocompromize is a matter of judgment left to those who are serving this subset of patients and observing the results of otherwise management strategies.

Though the authors believe that the findings here are clear indication for the efficiency of delayed debridement over the customary early one; it has to be noted that if this efficiency is ever to be attained there has to be a cover from, not only good, but indeed a very perseverant and dedicated ICU performance.

\section{REFERENCES}

1. Baharestani M (2008): Negative pressure wound therapy in the adjunctive management of necrotizing fasciitis: examining clinical outcomes. Ostomy Wound Manage, 54: 44-50. 75.

2. Bandyopadhyay D, Jacobs V and Panchabhai S (2016): What's new in emergencies, trauma and shock? The tortuous path in the management of necrotizing fasciitis: is early surgical intervention critical? J Emerg Trauma Shock, 9: 1-2.

3. Bucca K, Spencer R, Orford N, Cattigan C, Athan E and McDonald A (2013): Early diagnosis and treatment of necrotizing fasciitis can improve survival: an observational intensive care unit cohort study. ANZ J Surg, 83: 365-70.

4. Bulger M, Maier V, Sperry J, Manjari Joshi M, Henry S, Moore $F$, Moldawer $L$, Demetrios Demetriades D, Talving $P$, Schreiber M, Ham B, Cohen M, Opal S, Segalovich I, Maislin G, Kaempfer $R$ and Shirvan A (2014): A novel drug for treatment of necrotizing soft-tissue infections: a randomized clinical trial. JAMA Surg, 149:528-36.

5. Crew R, Varilla R, Rocas T III, Abdul Rani S and Debabov D (2013): Treatment of acute necrotizing fasciitis using negative pressure 
wound therapy and adjunctive NeutroPhase irrigation under the foam. Wounds, 25: 272-7.

6. Devaney B, Frawley G, Frawley L and Pilcher DV (2015): Necrotising soft tissue infections: the effect of hyperbaric oxygen on mortality. Anaesth Intensive Care, 43: 685-92.

7. Hadeed J, Smith J, O'Keeffe T, Kulvatunyou N, Wynne J, Joseph B, Friese R, Wachtel T, Rhee P, El-Menyar $A$ and Rifat Latifi (2016): Early surgical intervention and its impact on patients presenting with necrotizing soft tissue infections: a single academic center experience. J Emerg Trauma Shock, 9: 22-7.

8. Hakkarainen W, Kopari M, Pham N and Evans L (2014): Necrotizing soft tissue infections: review and current concepts in treatment, systems of care, and outcomes. Curr Probl Surg, 51: 344-62.

9. Howard $R$ (1999): Surgical infections. Schwartz S, Shires G, Spencer F, Daly J, Fischer $\mathbf{J}$ and Galloway A eds Principles of surgery. McGraw Hill. Singapore, 5; 124.

10. Jabbour G, El-Menyar A, Peralta R, Shaikh N, Abdelrahman H, Mudali IN, Ellabib M, and Al-Thani H (2016): Pattern and predictors of mortality in necrotizing fasciitis patients in a single tertiary hospital. World journal of emergency surgery. WJES, 11, 40.

11.Jallali N, Withey S and Butler PE (2005): Hyperbaric oxygen as adjuvant therapy in the management of necrotizing fasciitis. Am J Surg, 189:462-6.

12. Kadri S, Swihart J, Bonne L, Hohmann S, Hennessy L, Louras P, Evans H, Rhee C, Suffredini A, Hooper D, Follmann D, Bulger $\mathbf{E}$ and Danner $\mathbf{R}$ (2017): Impact of intravenous immunoglobulin on survival in necrotizing fasciitis with vasopressordependent shock: a propensity score-matched analysis from 130 US hospitals. Clin Infect Dis, 64:877- 85 .

13. Kulasegaran S, Cribb B, Vandal AC, McBride S, Holland D and MacCormick AD (2016): Necrotizing fasciitis: 11-year retrospective case review in South Auckland. ANZ J Surg, 86: 826-30.
14. Lee Y, Jung H, Kwon H and Jung N (2014): Extended negative pressure wound therapy assisted dermatotraction for the closure of large open fasciotomy wounds in necrotizing fasciitis patients. World J Emerg Surg, 9: 29.

15. Lenarz $\mathrm{C}$, Watson $\mathrm{J}$, Moed $\mathrm{B}$, Israel $\mathrm{H}$, Mullen J, Macdonald J (2010): Timing of wound closure in open fractures based on cultures obtained after debridement. J Bone Joint Surg Am, Aug 18; 92(10):1921-6.

16. Magala J, Makobore $P$, Makumbi $T$, Kaggwa S, Kalanzi $E$ and Galukande $M$ (2014): The clinical presentation and early outcomes of necrotizing fasciitis in a Ugandan Tertiary Hospital- a prospective study. BMC Research Notes, 7:476.

17. Marron D (2010): Superficial sepsis, cutaneous abscess and necrotizing fasciitis. Brooks A, Mahoney F, Cotton A and Tai N eds. Emergency surgery. Blacwell Publisching, 115-12.

18. Nordqvist $G$, Walldén $A$, Brorson $H$ and Tham J (2015): Ten years of treating necrotizing fasciitis. Infect Dis, 47: 319-325.

19. Puvanendran $R$ and Huey $C$ (2009): Necrotizing fasciitis. Can Fam Physician, 55:981-987.

20. Rhodes A, Evans LE, Alhazzani W, Alhazzani W, Levy M, Antonelli M, Ferrer R, Kumar A, Sevransky J, Sprung C, Nunnally M, Rochwerg B , Rubenfeld G, Angus D, Annane D, Beale R, Bellinghan G, Bernard G et al (2017): Surviving Sepsis Campaign: international guidelines for management of sepsis and septic shock: 2016. Intensive Care Med 2017; 43: 304-77.

21. Shah S, Hall M, Srivastava R, Subramony A and Levin E (2009): Intravenous immunoglobulin in children with streptococcal toxic shock syndrome. Clin Infect Dis, 49:1369-76.

22. Shaw J, Psoinos C, Emhoff A, Shah A and Santry P (2014): Not just full of hot air: hyperbaric oxygen therapy increases survival in cases of necrotizing soft tissue infections. Surg Infect15: 328-35.

23. Stevens L, Bisno L, Chambers F, Dellinger E, Goldstein E, Gorbach S, Hirschmann J, 
Kaplan S, Montoya J and Wade J (2014): Practice guidelines for the diagnosis and management of skin and soft tissue infections: 2014 update by the Infectious Diseases Society of America. Clin Infect Dis, 59(2): e10-e52.

24. Stevens L and Bryant A (2017): Necrotizing Soft-Tissue Infections. N Engl J Med, 377:2253-65.

25. van Stigt SF, de Vries J, Bijker JB, Mollen R, Hekma E, Lemson $S$ and Edward C
(2016): Review of 58 patients with necrotizing fasciitis in the Netherlands. World J Emerg Surg, 11: 21.

26. Wang C, Schwaitzberg S, Berliner E, Zarin DA and Lau J (2003): Hyperbaric oxygen for treating wounds: a systematic review of the literature. Arch Surg, 138:272-9.

27. Willy C, Rieger $H$ and Vogt $D$ (2012): Hyperbaric oxygen therapy for necrotizing soft tissue infections: contra. Chirurg, 83:960- 72. 


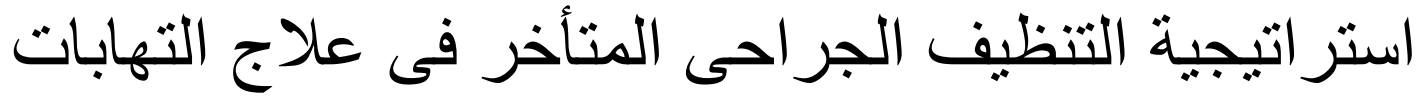

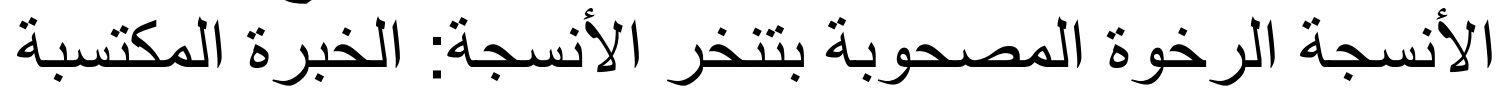

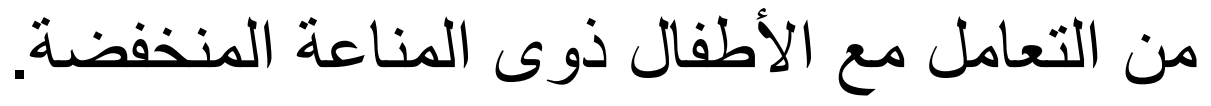
كريم سلام، ماجد مصطفى، لبنى شلبى، يوسف مدنى، على مصطفى، أميرة سيد، محمد

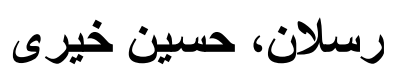

كريم سلام: قسم الجر احة، كلية الطب، جامعة حلوان

ماجد مصطقى: قسم الجراحة، معهد بحوث امر اض الكبد

لبنى شلبى، يوسف مدنى: قسم طب اور ام الأطفال، جامعة القاهرة

على مصطفى، أميرة سيد: قسم العناية المركزة، مستشفى سرطان الأطفال

محمد رسلان، حسين خيرى: قسم الجر احة، كلية الطب جامعة القاهرة

kareem.sallam@med.helwan.edu.eg للمراسلة:كريم سلام،

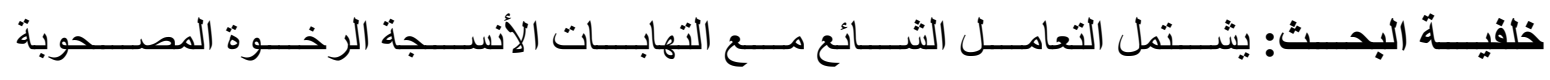

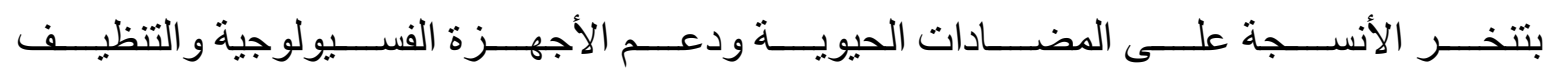

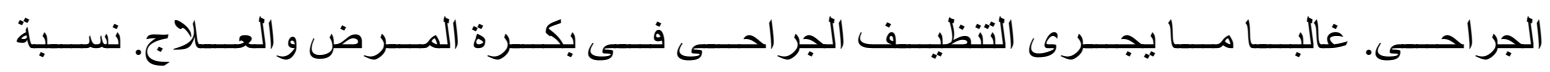
الوفاة من هذا المرض لا تز ال مرتفعة.

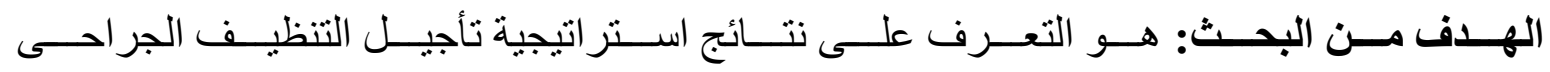
اللمرضى موضوع البحث.

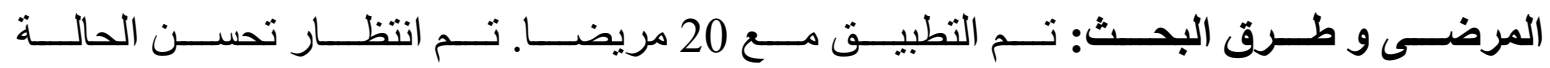

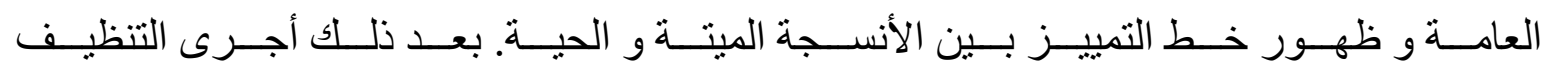
الجر احى بغرفة العمليات حيث نم استنصسال الأنسجة الميتة(المتنخرة) فقط.

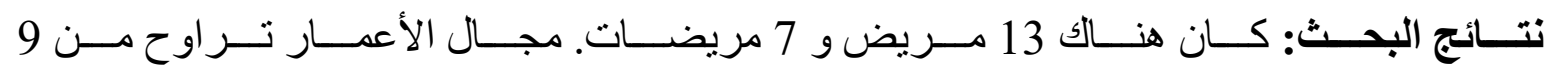

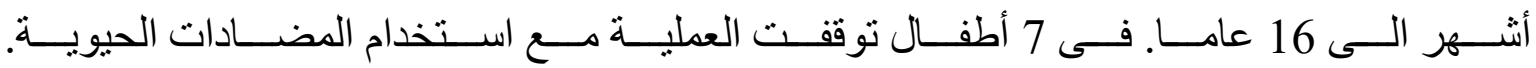

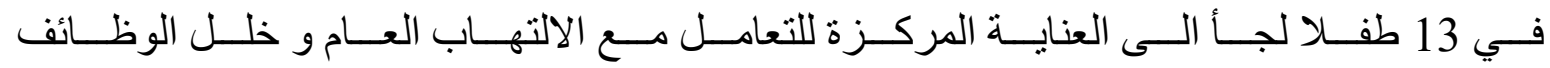

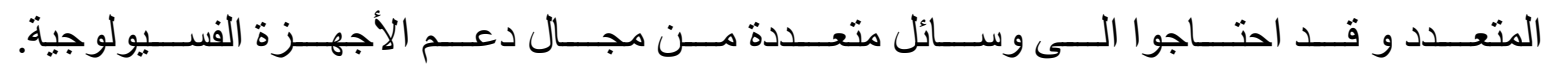




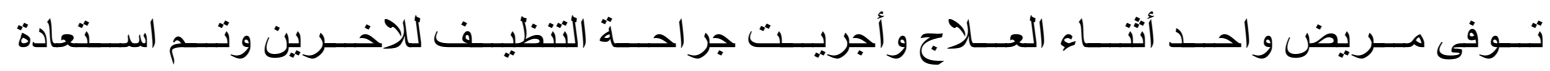

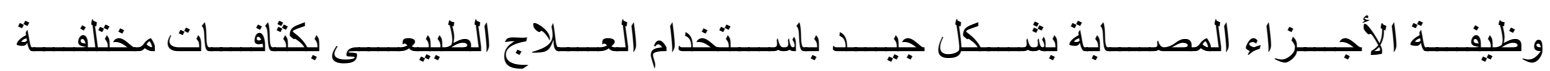
حسب الاحتياج.

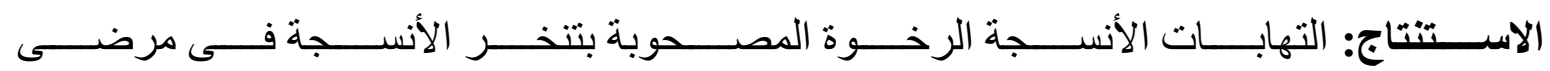

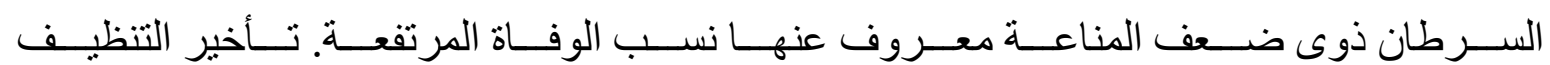

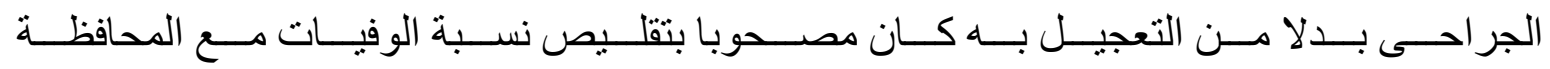
على الجزء (الطرف) المصاب. الكلمات الدالة: التنظيف الجر احى، تتخر الأنسجة. 